\title{
The effects of service operation engineering and green marketing on consumer buying interest
}

\author{
Yosi Pahala $^{\mathrm{a}}$, Sri Widodo ${ }^{\mathrm{b}}$, Kadarwati $^{\mathrm{b}}$, Munir Azharic ${ }^{\mathrm{c}}$, Muliyatid, Novia Indah Lestari ${ }^{\mathrm{e}}$, Suharto Abdul \\ Madjid $^{\mathrm{a}}$, Sonya Sidjabat ${ }^{\mathrm{a}}$, Nandan Limakrisna ${ }^{\mathrm{f}}$ and Endri Endri ${ }^{\mathrm{g}^{*}}$
}

${ }^{a}$ Institut Transportasi dan Logistik Trisakti, Jakarta. Indonesia

${ }^{b}$ Universitas Dirgantara Marsekal Suryadarma, Jakarta. Indonesia

${ }^{c}$ STIMA IMMI, Jakarta. Indonesian

${ }^{d}$ Institut Bisnis dan Informatika Kosgoro 1957, Jakarta, Indonesia

eUniversitas Serang Raya, Serang, Banten, Indonesia

${ }^{f}$ Universitas Persada Indonesia Y.A.I, Jakarta, Indonesia

${ }^{g}$ Universitas Mercu Buana, Jakarta, Indonesia

\section{H R O N I C L E}

Article history:

Received February 2, 2021

Received in revised format May

20, 2021

Accepted May 302021

Available online

May 302021

Keywords:

Service operation engineering

Green marketing

Consumer buying interest

\section{A B S T R A C T}

The purpose of this research is to determine the effects of service operation engineering and green marketing on consumer buying interest in a company in Jakarta. The analysis used in this research is a quantitative analysis technology using the statistical program analyzed by the SPSS 21 version of the program. In this study, the sample size is as many as 145 people. The data in this study are raw data, obtained through field research using questionnaire survey methods. The questionnaire survey method is a method of collecting data using a list of questions that must be filled out by the interviewee. The results of the survey indicate that service operation engineering and green marketing had some positive effects on consumers' buying interest. Service operation engineering has a dominant effect on consumer buying interest. For increasing consumer buying interest, service operation engineering is very important, since green marketing will implement service operation engineering support.

\section{Introduction}

Global warming is an issue that is heard everywhere today, where the world is affected, forest destruction, changes in temperature, increasingly unstable climate, depletion of the ozone layer and so on. Many environmental organizations have started to emerge to encourage and make people aware of the importance of maintaining environmental quality. Service operation engineering and green marketing is not new. The term service operation engineering and green marketing is one of the strategic initiatives to create an environment-based and health-based business, and it has become widely known in the late 1980s and early 1990s. Bell and Emeri and Feldman have introduced this concept since 1971. They pointed out that the marketing concept was misplaced because it was limited to satisfying consumer needs but ignored the long-term benefits of society and the environment. There is external pressure and consumer demand, which may be caused by increased environmental pollution (Syafei et al., 2020). A company can be said to be green if in all dimensions of its company's activities it includes environmental considerations (Joshi \& Rahman, 2015). Environmental damage and global warming are the biggest problems facing the world in the midst of the development of the globalization era. One of the causes of global warming is the result of the continuous use of dangerous products. Globalization makes it easy for people to obtain information about global environmental issues such as global warming, including damage to forests, an increasingly unstable climate, changing temperatures, depleting ozone layer and so on. Service operation engineering and green marketing is defined as the consistency of all activities that design services and facilities to meet the needs and desires of consumers without affecting the natural environment (Laroche et al., 2001). Therefore, service operation engineering and green marketing integrate broad activities such as modifying products, changes in production processes, on product packaging, to changes in advertising.

* Corresponding author Tel.: +628129204067

E-mail address: endri@mercubuana.ac.id (E. Endri)

(c) 2021 Growing Science Ltd. All rights reserved. doi: $10.5267 /$ j.uscm.2021.5.011 
Service operation engineering and green marketing refers to the satisfaction of needs, the desire of customers to build relationships for the maintenance and preservation of the environment. Furthermore, in Business, it is conveyed that the awareness of the world community on the importance of environmental preservation is caused by the great concern that environmental disasters will threaten, not only health, but also the survival of humans and their descendants.

\section{Literature review}

\subsection{Consumer buying interest}

According to Chen et al. (2018), consumers' interest in buying (purchasing intention) is as follows: buying intention, once the friend is evaluated, the consumer intends to buy the friend with the highest level of expected satisfaction. The definition of consumer buying interest is that after consumers first evaluate a certain kind of trust and will buy the trust that can provide the highest expected satisfaction, the conditions for consumer buying interest appe According to Morwitz (2012), purchase interest is consumer behavior that appears in response to objects that indicate a person's desire to make a purchase. While the notion of buying interest according to $\mathrm{Bu}$ et al. (2020), a person's attitude model towards commodity objects is very suitable for measuring attitudes towards certain products, services or beliefs. It can be concluded that interest in someone shows a tendency to focus on objects that attract him. Basically, someone's interest arises because of his own internal and external influences, that is, the environment in which the individual is located. Therefore, it can be said that buying interest is a trend, and people's enthusiasm for buying a certain product is high, or a strong desire to buy. The factors that affect product purchase come from inside and outside of the person, that is, the position of the individual. According to Chen et al. (2018), factors that affect consumers' buying interest include: 1) the environment; the surrounding environment will affect consumers' buying interest when choosing a particular product, and 2) marketing incentives. Marketing aims to stimulate consumers and enable them to attract buying interest, including attractive advertising. Purchasing interest is determined by influence, consumer's attitude towards products and belief in quality. In this case, marketers must understand consumer needs. Consumer buying interest refers to the attitude, interest and behavior of consumers in the decision-making process and when planning to purchase multiple brands. The interests of consumers are strongly influenced by the characteristics of the product, the choice of product interests, and the price determined by the marketer. Service operation engineering and green marketing is a marketing strategy that can have an impact on consumer behavior (Taghian et al., 2016). The goal of a service operation engineering and green marketing strategy is to provide satisfaction to environmentally friendly consumers so that consumers are attracted to environmentally friendly behavior. In addition, service operation engineering and green marketing is used to develop effective marketing strategies that are committed to environmentally friendly purchasing practices, marketing strategy is gaining traction as a strategic initiative in retail sector companies and is used as a tool to enhance the company's image and business performance (Taghian et al., 2016). In the practice of service operation engineering and green marketing strategy, companies basically must educate consumers where consumers must be aware of what they buy and consume because marketers can be misleading. Therefore, consumers must increase their level of environmental awareness and the important role they play in protecting the environment by changing their buying habits (Nekmahmud \& Fekete-Farkas, 2020). Consumers are very aware of environmental problems such as global warming and the impact of environmental pollution. In order to win the competition, marketers must react quickly to changing demand, satisfying all customer needs and wants, because the marketing base is customer oriented. The market potential for any product is equal to the number of people who want or need it and also have the necessary resources to buy it. Therefore, we need to evaluate the demographic characteristics of current and potential buyers. When customers are ready, people who realize and care about how the environment affects people's habits often want environmentally friendly products. This behavior can be seen from consumers' attitude towards protecting the surrounding environment, which is increasingly inclined to purchase environmentally friendly products. Following this is the emergence of green consumer communities, who hope that environmentally friendly products will cause the least damage to the environment, which makes many industries begin to adapt to environmental issues in every activity, first to consider each raw material and the environmental impact caused by it. Marketing activities are always present in every business, both profit-oriented and social enterprises. The importance of marketing is done in order to meet the needs and desires of the community for a product or service. Marketing is becoming increasingly important as people's knowledge increases. The marketing process is an important part of offering merchandise to prospective buyers. Marketing can also be done in order to face competitors who are increasing from time to time. If an entrepreneur has good marketing management, his business will grow quickly. The success of a company's business is determined by its marketing success. Marketing people are attracted to the beliefs that someone formulates about certain products and services, because trust constructs a product image that influences purchasing behavior. If this belief is wrong and gets in the way of buying, the marketing person will put out an ad to correct that belief. Trust in the brand will be formed with a certain period after consumers feel the satisfaction obtained from the advantages and benefits obtained after consuming a product. Before consumers decide in choosing a product brand, consumers must make an assessment before buying to trust a brand. Consumer trust in a brand is obtained after the closeness of a positive emotional relationship between the company and the consumer. A product offered by a capable company can be one of the attractions for the formation of consumer buying interest in making purchasing decisions. Purchase interest is something related to the consumer's plan to buy a certain product, as well as how many units of the product are needed in a certain period. In order to win the competition, the company tries to apply the right marketing concept known as the 4P, namely Product, Price, Place and Promotion. Theoretically, the buying interest made by consumers for the goods offered is strongly influenced by location, facilities and product diversity. In connection with the existence of consumers and 
the diversity of individual behavior, companies must be responsive to what must be done in relation to the survival of their business, because consumers are increasingly selective in making purchases to meet their needs. Needs can be in the form of daily needs (family), study needs, employment, economic status, social status and other needs. Thus, one of the factors that determines the success of a company to stay ahead of the competition, depends on the company's ability to provide various products or goods so that it becomes a consumer choice. The relationship of high consumer purchase interest will encourage consumers to buy a product and vice versa, if consumer buying interest is low, it will prevent consumers from buying the product. Green advertising develops collectively with the inexperienced patron motion across the world. The inexperienced patron motion is an ethical motion whose reason is to defend environmental lifestyles to make it more livable, and its essence is to inspire adjustments in people's behavior. No one cared about the surroundings before, or maybe the surroundings. Service operation engineering and green marketing essentially describes product marketing based on environmental performance. According to Sarkar (2012), service operation engineering and green marketing is defined as a marketing response to environmental influences originating from the design, production, packaging, labeling, use and disposal of goods or services. According to Choudhary and Gokarn (2013), service operation engineering and green marketing refers to all marketing activities that are responsible for the environment, that is, the least negative impact on the environment. In 1976, Kotler introduced the concept of social marketing to fulfill the social responsibilities of marketers, including four aspects to be considered when making marketing decisions, namely: consumer desires, consumer interests, the requirements of the company and the welfare of the social environment (Lantos, 2002). This concept states that the assignment of the enterprise is to decide the needs, wants, and hobbies of the target market, and to offer pleasure extra successfully and successfully compared to competition through defensive or enhancing the welfare of customers and society. Peattie (2001) defines service operation engineering and green marketing as a holistic management process that is responsible for identifying, anticipating and satisfying the desires of consumers and society in a profitable and sustainable way. Meanwhile, Taghian et al. (2016) states that service operation engineering and green marketing are all activities designed to supply and facilitate all adjustments which are predicted to satisfy human desires and dreams, with minimum effect at the destruction of the herbal environment. This takes place because meeting human dreams and desires may also moreover have a terrible impact on the natural environment. From those definitions, it may be concluded that inexperienced advertising and marketing consists of numerous vital aspects, namely: First, the business enterprise or agency attempts to satisfy the desires and dreams of clients through its advertising and marketing sports, and those advertising and marketing sports are achieved in an extra powerful manner. Compared with competitors, those 3 sports have little effect at the destruction of the herbal environment, thereby enhancing the wellbeing of clients and society. The advantages of inexperienced advertising, inexperienced advertising is an increasing number of appealing ideas for academics, practitioners, public regulatory agencies, customers and those who care about the environment. The reason why this idea is so critical to the enterprise is a famous easy purpose, that is, restrained resources. It is talked about withinside the economics literature that economics is the examination of ways human beings meet their wishes and wishes through pleasing wishes or restrained resources. The existing resources in the world are natural resources limited to a limited number. The functioning of temporary resources will damage the environment and undermine the well-being of well-being and consumer society. From the point of view of vision, the limited resources of the company are looking for new ways to meet the needs of consumers. Service operation engineering and green marketing Concept is an alternative to marketing specialists for marketing activities through the effective use of limited resources. Through the concentration of service operation engineering and green marketing, there will be direct benefits: 1). Production of environmentally friendly products 2). Producers and advertisers develop products that they strive to meet the needs of people who care about the environment 3). innovation. The love for the environment will make the company more innovative, in terms of input, process, output and even marketing strategies. According to Dapas et al. (2019), buying interest is the stage of the respondent's tendency to act before the buying decision is carried out. Meanwhile, according to Rehman et al. (2014), The hierarchical effect of buying interest is used to describe the process sequence of belief generation. Consumers have attitudes (attitudes) and knowledge behavior cognitions through associated attributes, interests and objects (by evaluating information), and attitudes refer to feelings or effective responses (McLaughlin, 2010). According to Effendy et al. (2005), expressing interest is the continuation of attention which is the starting point for the continuation of the desire to carry out the expected activities. Meanwhile, according to Harackiewicz and Hulleman (2010), interest is a tendency and high enthusiasm or a great desire for something. According to Morwitz (2012), consumer buying interest is something related to consumer plans to buy certain products, and how many units of product are needed in each period. Purchasing interest is related to a consumer's plan to purchase a certain product and how many products are needed in a certain period. It can be said that purchase intention is a mental statement of consumers, reflecting the purchase plan of certain products with certain beliefs. It is very necessary for large enterprises to determine consumers' interest in purchasing a certain product. Marketers and economists use interest variables to predict future consumer behavior.

\subsection{Service operation engineering}

Service operations management is the implementation of organizational strategy through operational controls that focus not only on product or service development, but also delivery of products and services to end customers in a way that encourages mutual value creation between the customer and the company (Payne et al. 2008). Wen (2012) empirically examines the structural model of the factors that influence consumers' online purchase intentions for travel products. The findings indicate that information quality, service quality, and system quality are valid measures for evaluating the quality of a travel-oriented website design. The quality of travel website design, tourist attitudes, and customer satisfaction show a significant influence 
on tourist purchase intentions. The results of research by Zarei et al. (2019) show that purchase intention via the Internet has a significant influence on buying behavior via the Internet. In addition, purchase intentions via the Internet mediate the relationship between Internet buying attitudes and Internet buying behavior. Thus, the quality of Internet service can measurably affect purchasing behavior over the Internet. Lu and Su (2009) explored a conceptual model to analyze customer perceptions of using mobile trading services for online shopping. The results showed that anxiety, which is an effective barrier to the use of innovative systems, is a major negative predictor of customer intention. Tamaruddin et al. (2020) proved that technology services had no direct relationship with customer satisfaction and loyalty.

\subsection{Green Marketing}

Green marketing has become an interesting topic for companies, because today's consumers are not only aware of the various brands and qualities, they perceive but also, they are starting to pay more attention to the environment so that consumers become more environmentally friendly. Therefore, companies must explore various ways to communicate with customers so that customers remain loyal for a long time by adopting green management. Research by Saini (2013) shows that companies need to improve their communication with customers to go green, and that attributes such as price and quality are more important than environmental responsibility. Green marketing integrates various activities, from product modification, production method changes, packaging changes, price changes, and promotional theme modifications. Hossain and Khan (2018) prove that green products and green promotion are important elements that influence consumer purchasing decisions. By using Theory of Planned Behavior (TPB), Nekmahmud and Fekete-Farkas (2020), adding environmental problems, qualities that are considered environmentally friendly, and the future of green forecasts in their research. The results show that consumer environmental concern, perceived green benefits, green price awareness, green willingness to buy, and future forecasts of green marketing have a strong positive influence on consumers' eco-friendly purchasing decisions. Ansar (2013) examines the factors that determine consumer intentions to buy environmentally friendly products. The results showed that age and education had a positive relationship with Eco-literacy. Socio-demographic variables do not have a significant relationship with green purchase intention. In addition to this Environmental advertisement, Ecology price and packaging were found to be positively related to Green purchase intention.

\section{Method}

This study is a type of quantitative research and field procedure. This type of research is quantitative because it believes that reality / phenomena is classified, relatively fixed, specific, observed and measurable and interrelationship between symptoms is causal. This study was conducted in certain population groups and representative models. The research process is reduced, because the formulation of the response to the concepts / theory of applications is used to form a hypothesis. Then test the hypothesis through field data collection. The research data was analyzed using the SPSS 21 version as an analysis tool. In SPSS, the raw data that has been processed into numbers is input into SPSS, which makes it easier for the author to conduct this research. The population in this study is a client of a state-owned company with 145 employees. The sample in this study has as many as 85 customers. The data in this study are raw data, obtained through field research using questionnaire survey methods. The questionnaire survey method is a method of collecting data by using a list of questions or statements that must be filled out by the interviewee.

\section{Results and discussion}

The analysis and hypothesis testing method in this study is a quantitative study and uses field methods. This type of research is quantitative because it believes that reality/phenomena can be classified, relatively fixed, specific, observable, measurable, and the relationship between symptoms is causal. This research was conducted on specific representative populations and samples. The research process is deductive in nature because the formulation to answer the question will use concepts/theories to formulate hypotheses. Then test the hypothesis through field data collection. The structural equation modeling tool called SPSS Analysis version 20 was used as the analysis tool to analyze the data of this study. The result of hypothesis testing can see in Table 1.

Table 1

\begin{tabular}{lllll}
\hline \multicolumn{2}{r}{ Path Coefficient } & $\mathbf{T}_{\text {value }}$ & $\mathbf{t}_{\text {table }}$ & \multicolumn{1}{c}{ Conclusion } \\
\hline PYX $_{1}$ & 0,412 & 3,243 & 1,645 & $\begin{array}{l}\text { Ho Rejected } \\
\text { There is positive effect Service Operation Engineering on Consumer Behavior Intention }\end{array}$ \\
PYX $_{2}$ & 0,291 & 2,287 & 1,645 & $\begin{array}{l}\text { Ho Rejected } \\
\text { There is positive effect Geen Marketing on Consumer Behavior Intention }\end{array}$ \\
\hline Soure: & & &
\end{tabular}

Based on the results of the calculation of the value of the variable path coefficient (X1) and (X2) against (Y), which was obtained using the SPSS release 21 for windows program, thus in accordance with the rule of decision, that the falling prices in the area $\mathrm{H} 0$ are rejected, meaning that the path coefficient is significant, so that the path diagram does not change. Conceptually, it can be explained that all aspects of Service Operation Engineering and aspects of Green Marketing have a positive effect on Consumer Behavior Intention. From the results of hypothesis testing between $\mathrm{X}$ and $\mathrm{Y}$ variables, there is a direct relationship between Service Operation Engineering and Green Marketing variables on Consumer Behavior Intention, a complete diagram of the causal relationship of variables $\mathrm{X} 1$ and $\mathrm{X} 2$ to $\mathrm{Y}$ is as follows: 


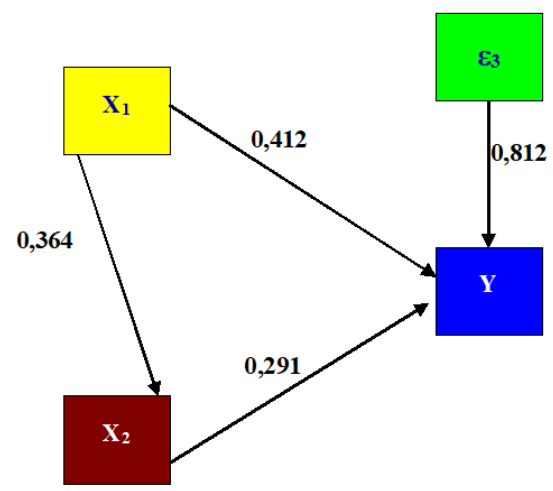

Fig. 1. Path Analysis for Service Operation Engineering (X1) and Green Marketing (X2) on Consumer Behavior Intention (Y)

From Fig. 1 the structural causal relationship between variables with the structural parameter values above, then the influence of the causal variable to the variable, then the effect of Service Operation Engineering and Green Marketing on Consumer Behavior Intention:

Table 2

The influence of $\mathrm{X}_{1}$ and $\mathrm{X}_{2}$ on $\mathrm{Y}$ also outside effect $\mathrm{X}_{1}$ and $\mathrm{X}_{2}$ Variables

\begin{tabular}{lcc}
\hline Comments & Influence & $\%$ \\
\hline The effects of $\mathrm{X}_{1}, \mathrm{X}_{2}$ on $\mathrm{Y}$ & 0,341 & 34,1 \\
Outside Effercts for $\mathrm{X}_{1}$ and $\mathrm{X}_{2}$ & 0,659 & 65,9 \\
\hline Amount & & 100
\end{tabular}

Source : SPSS Statistical Program Result

From the test results, Service Operation Engineering and Green Marketing influence Green Marketing, which is 34.1\%, while the remaining $65.9 \%$ is influenced by other factors not examined by the author. However, if seen partially, Service Operation Engineering is more dominant in influencing revenue than Green Marketing. This can be understood because each indicator of Service Operation Engineering and Green Marketing is used as an aspect of measuring Consumer Behavior Intention. If the government wants high Green Marketing, it must be able to create a more conducive Service Operation Engineering together with increasing motivation. Through the concentration of service operation engineering and green marketing, there will be direct benefits: 1). Production of environmentally friendly products 2). Producers and advertisers develop products that they strive to meet the needs of people who care about the environment 3 ). innovation. The love for the environment will make the company more innovative, in terms of input, process, output and even marketing strategies. According to Dapas et al. (2019), buying interest is the stage of the respondent's tendency to act before the buying decision is carried out. Meanwhile, according to Cohen et al. (2014), the hierarchical effect of buying interest is used to describe the process sequence of belief generation. Consumers have attitudes (attitudes) and knowledge behaviours cognitions through associated attributes, interests and objects (by evaluating information), and attitudes refer to feelings or effective responses. According to Effendy et al., (2005), expressing interest is the continuation of attention which is the starting point for the continuation of the desire to carry out the expected activities. Meanwhile, according to Win (2018), interest is a tendency and high enthusiasm or a great desire for something. According to Morwitz (2012), consumer buying interest is something related to consumer plans to buy certain products, and how many units of product are needed in each period. Meanwhile, according to Dachyar and Banjarnahor (2017), purchasing interest is related to a consumer's plan to purchase a certain product and how many products are needed in a certain period. It can be said that purchase intention is a mental statement of consumers, reflecting the purchase plan of certain products with certain beliefs. It is very necessary for large enterprises to determine consumers' interest in purchasing a certain product. Marketers and economists use interest variables to predict future consumer behaviours.

\section{Conclusion}

After describing the effect of service operation engineering and green marketing on consumer buying interest, from the results of the analysis and discussion in the previous section, the author will draw a conclusion from the results of this discussion as follows; Service operation engineering and green marketing have positive effects on consumer buying interest. Service operation engineering has a dominant effect on consumer buying interest. For increasing consumer buying interest, service operation engineering is very important, since green marketing will implement service operation engineering support.

\section{References}

Ansar, N. (2013). Impact of Green Marketing on Consumer Purchase Intention. Mediterranean Journal of Social Sciences, 4(11), 650.

Bu, X., Nguyen, H.V., Chou, T.P., \& Chen, C.P. (2020). A Comprehensive Model of Consumers' Perceptions, Attitudes and Behavioral Intention toward Organic Tea: Evidence from an Emerging Economy. Sustainability, 12(16),6619. https://doi.org/10.3390/su12166619 
Chen, C.C., Chen, C.W., \& Tung, Y.C. (2018). Exploring the consumer behavior of intention to purchase green products in belt and road countries: An empirical analysis. Sustainability, 10(3), 854. DOI:10.3390/su10030854

Cohen, S.A., Prayag, G., \& Moital, M. (2014). Consumer behaviour in tourism: concepts, influences and opportunities. Current Issues in Tourisn, 17(10), 872-909. https://doi.org/ 10.1080/13683500.2013.850064

Choudhary, A., \& Gokarn, S. (2013). Green marketing: a means for sustainable development. Journal of Arts, Science and Commerce, 4(3), 3.

Dachyar, M., \& Banjarnahor, L. (2017). Factors influencing purchase intention towards consumer-to-consumer e-commerce. Intangible Capital, 13(5), 946-966.

Dapas, C. C., Sitorus, T., Purwanto, E., \& Ihalauw, J. J. (2019). The effect of service quality and website quality of Zalora. com on purchase decision as mediated by purchase intention. Quality-Acces to Success, 20(169), 87-92.

Effendy, I., Lecha, M., Feuilhade de Chauvin, M., Di Chiacchio, N., \& Baran, R. (2005). Epidemiology and clinical classification of onychomycosis. Journal of the European Academy of Dermatology and Venereology, 19(1), 812.https://doi.org/10.1111/j.1468-3083.2005.01281.x

Harackiewicz, J. \& Hulleman, C. (2010). The Importance of Interest: the role of achievement goals and task values in promoting the development of interest. Social and Personality Psychology Compass, 4(1), 42-52.

Hossain, A., \& Khan, M. Y. H. (2018). Green marketing mix effect on consumers buying decisions in Bangladesh. Marketing and Management of Innovations, 10(4), 298- 306.

Joshi, Y., \& Rahman, Z. (2015). Factors affecting green purchase behaviour and future research directions. International Strategic management review, 3(1-2), 128-143. https://doi.org/10.1016/j.ism.2015.04.001

Lantos, G.P. (2002). The ethicality of altruistic corporate social responsibility. Journal of Customer Marketing, 19(3), 205232

Laroche, M., Bergeron, J., \& Barbaro-Forleo, G. (2001). Targeting consumers who are willing to pay more for environmentally friendly products. Journal of Consumer Marketing, 18(6), 503-520.

Lu, H. P., \& Su, Y. J. P. (2009). Factors affecting purchase intention on Mobile shopping websites. Internet Research, 19(4), 442-458. https://doi.org/10.1108/10662240910981399

McLaughlin, S. (2010). Service operations and management. In G. Salvendy \& W. Karwowski (Eds.), Introduction to service engineering (pp. 295-315). John Wiley \& Sons, Inc. https://doi.org/10.1002/9780470569627.ch14

Morwitz, V. (2012). Consumers' Purchase Intentions and their Behavior. Foundations and Trends in Marketing, 7(3), 181230.

Nekmahmud, M., \& Fekete-Farkas M.(2020). Why Not Green Marketing? Determinates of Consumers' Intention to Green Purchase Decision in a New Developing Nation. Sustainability, 12(19),7880. https://doi.org/10.3390/su12197880

Payne, A.F., Storbacka. K., \& Frow, P. (2008) Managing the co-creation of value. Journal of the Academy of Marketing Science, 36(1),83-96. DOI:10.1007/s11747-007-0070-0

Peattie, K. (2001). Towards sustainability: The third age of green marketing. The Marketing Review, 2 (2), $129-146$.

Rehman, F.U., Javed, F., Nawaz, T., Ahmed, I., \& Hyder, S. (2014). Some Insights in the Historical Prospective of Hierarchy of Effects Model: A Short Review. Information Management and Business Review, 6(6), 301-308.

Saini, B (2013). Green marketing and its impact on consumer buying behavior. International Journal of Engineering Science Invention, 2(12), 61-64.

Sarkar, A. N. (2012). Green Branding and Eco-innovations for Evolving a Sustainable Green Marketing Strategy. AsiaPacific Journal of Management Research and Innovation, 8(1), 39-58. DOI: 10.1177/2319510X1200800106

Syafei, M., Budi, D. R., Listiandi, A. D., Festiawan, R., Kusnandar, K., Nurcahyo, P. J., Stephani, M. R., \& Qohhar, W. (2020). Functional Movement Screening: An Early Detection of The Student Injury Risk in Sport Class. Jurnal Pendidikan Jasmani Dan Olahraga, 5(2), 182-191. DOI: https://doi.org/10.17509/jpjo.v5i2.25466

Taghian, M., Polonsky, M., \& D’Souza, C.(2016). Green marketing strategies. In An Integrated Approach to Environmental Management; Sakar, D., Datta, R., Mukherjee, A., Hannigan, R., Eds.; John Wiley \& Sons, Inc.: New York, NY, USA

Tamaruddin., Firdaus, A., \& Endri, E. (2020). Customer Satisfaction Mediates the Effect of Self Service Technology on Customer Loyalty in of Islamic Bank E-Banking Services in Indonesia. ILTIZAM Journal of Shariah Economics Research, 4(2), 1-15. DOI: : https://doi.org/10.30631/iltizam.v4i2.596

Wen, I. (2012). An Empirical Study of An Online Travel Purchase Intention Model. Journal of Travel and Tourism Marketing, 29(1), 18-39.DOI: $\underline{10.1080 / 10548408.2012 .638558}$

Win, M. M., (2018). Motivational Factors to Promote Students ${ }^{e e}$ Interest and Involvement in Teaching-Learning English. PEOPLE: International Journal of Social Sciences, 4(3), 224-237. https://dx.doi.org/10.20319/pijss.2018.43.224237

Zarei, G., Asgarnezhad Nuri, B., \& Noroozi, N. (2019). The effect of internet service quality on consumers' purchase behavior: The role of satisfaction, attitude, and purchase intention. Journal of Internet Commerce, 18(2), 197-220. DOI: $10.1080 / 15332861.2019 .1585724$

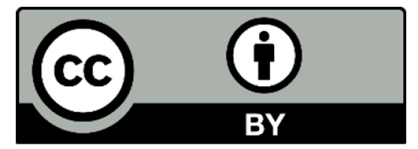

(C) 2018 by the authors; licensee Growing Science, Canada. This is an open access article distributed under the terms and conditions of the Creative Commons Attribution (CCBY) license (http://creativecommons.org/licenses/by/4.0/). 